\title{
太田川放水路における塩水遡上と 懸濁粒子の輸送特性 \\ TRANSPORT CHARACTERISTICS OF SALT WATER AND SPM IN THE OHTAGAWA DIVERSION CHANNEL
}

\author{
川西 澄 1 ・胡桃田哲也 ${ }^{2} \cdot$ Mahdi RAZAZ ${ }^{3} \cdot$ 水野雅光 $^{4} \cdot$ 福岡捷二 5 \\ Kiyosi KAWANISI, Tetsuya KURUMIDA, Mahdi RAZAZ, \\ Masamitu MIZUNO and Shouji FUKUOKA
1 正会員 工博 広島大学大学院准教授 工学研究科社会環境システム（テ 739-8527 東広島市鏡山 1-4-1）
2 学生員 広島大学大学院博士課程前期 工学研究科社会環境システム（同上）
3 学生員 広島大学大学院博士課程後期 工学研究科社会環境システム (同上)
4 正会員国土交通省中国地方整備局太田川河川事務所（干 730-0013 広島市中区八丁堀 3 番 20 号） \\ 5 フェロー会員 工博 中央大学研究開発機構教授（７ 112-8551 東京都文京区春日 1-13-27）
}

\begin{abstract}
Long-duration observations of salinity distribution were conducted at $4.8 \mathrm{~km}$ upstream from the mouth of the Ohtagawa diversion channel where flow and density conditions change significantly. In addition, measurements of tidal current and suspended particulate matter (SPM) were carried out, using an acoustic Doppler current profiler. The long deployment periods allowed us to examine the effect of a flood incident, wind, mean depth, and both semi-diurnal and neap/spring aspects of tides. The influences of the river discharge, wind, tidal range, and mean depth on the transport of saltwater and SPM were examined by the regression analysis. The direction of the mean SPM transportation was toward upstream for the restricted freshwater discharge. The upstream SPM flux increased with the increasing tidal range. Conversely, the intrusion of salt water was suppressed by the tide.
\end{abstract}

Key Words: saltwater intrusion, SPM, stratification, density current, tidal flow, wind-driven current, estuaries

\section{1.はじめに}

広島市の太田川放水路は, 最大潮差が $4 \mathrm{~m}$ と大き く, 平均水深と潮差が同程度であることに加え, 放 水路上流端に位置する祇園水門の操作によって著し い非定常性を示す水域である。太田川放水路の河岸 沿いには良好な干潟が形成されており，中流域には フクド，八マサジなどの塩生植物の群落がみられる.

太田川放水路では今後の河川整備のために, 治水 上の問題に加えて河川環境の把握と評価が求められ ているが，感潮河川の環境を適切に保全していくた めには，時々刻々大きく変動している塩分と流動を 長期にわたって観測し，様々な時間スケールの変動 と変動要因を把握しておく必要がある．著者らはこ れまでに放水路下流部において ADP 観測を行うとと もに，数值モデルを用いて風と潮汐が放水路内の塩 水遡上や懸濁粒子の輸送に与える影響を検討してき $た^{1-3)}$.
本論文では出水期と平水期に放水路中流部で 4 ケ 月にわたる塩分の鉛直分布の連続観測を 2 回実施す るとともに，2 ケ月間の ADPによる流速分布の測定 を行い, 塩水遡上, 残差流と䀣濁粒子輸送量の長期 変動特性と変動に対する河川流量, 風, 潮差と平均 水深の影響を明らかにする.

\section{2. 観測地点と観測方法}

広島市西部に位置する太田川放水路の河口から約 $4.8 \mathrm{~km}$ 上流で塩分・水温と流速の鉛直分布の連続観測 を行った。観測地点を図-1に示す.太田川は河口から 約 $9 \mathrm{~km}$ 上流で放水路と市内派川に分派しており，放 水路上流端には祇園水門, 市内派川側には大芝水門 が設置されている。平常時, 祇園水門は 3 つのゲー 卜の内, 右岸側のゲートのみが開度 $0.3 \mathrm{~m}$ に設定され ており他の 2 つは閉じられている。一方，市内派川 


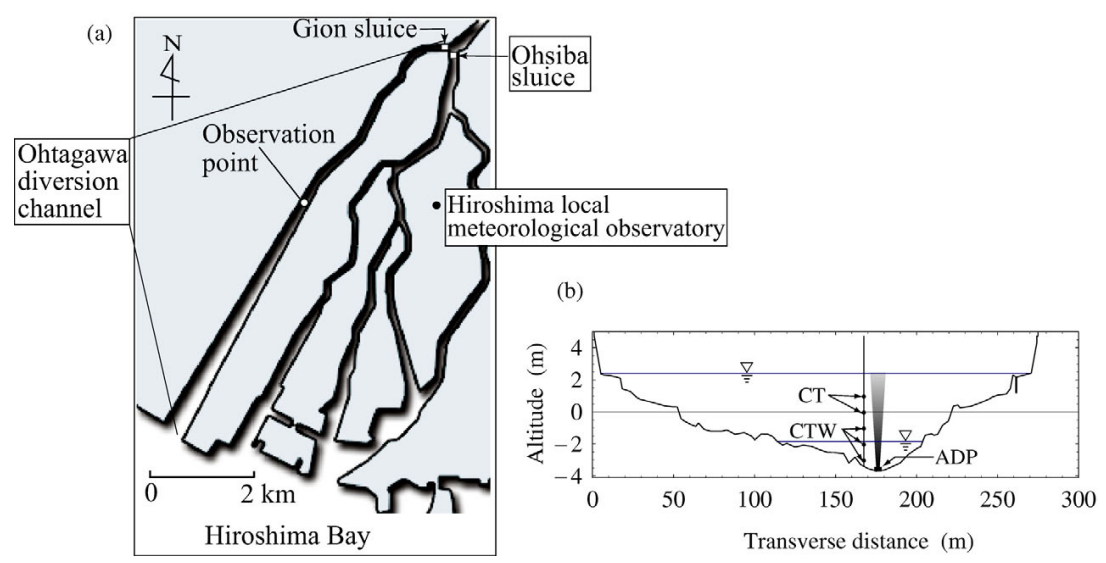

図-1 観測地点 (a) と水路横断面形および測器の配置 (b)

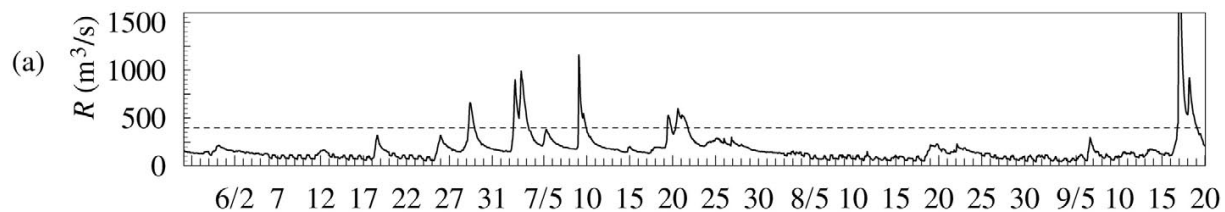

$0 \quad$ Salinity, $S \quad 31$

(b) $\underbrace{\mathrm{g}}_{\mathrm{N}}$

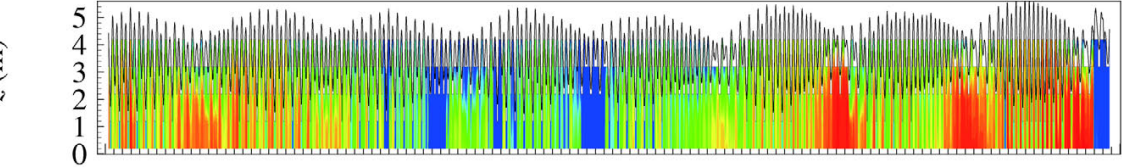

(c) is

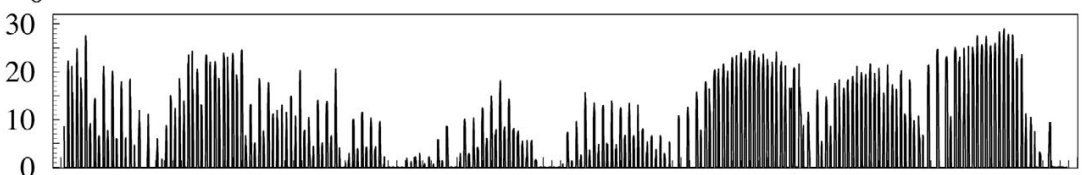

(d)

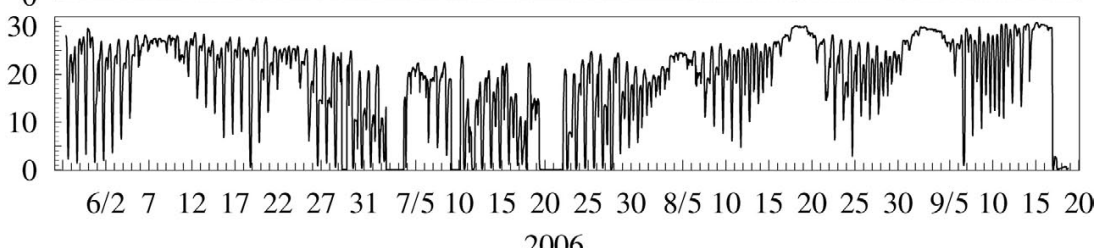

図-2 出水期における河川流量 $(\mathrm{a})$, 塩分の時空間分布 $(\mathrm{b})$, 上層塩分 $(\mathrm{c})$ と底層塩分 $(\mathrm{d})$ の経時変化

側の大芝水門は全開となっている。感潮域であるた め，正確な放水路への流入流量データはないが，平 常時，太田川流量の約 $10 \%$ が流入していると考えら れている. 太田川流量が $400 \mathrm{~m}^{3} / \mathrm{s}$ を超えると水門は 全開となり太田川流量の半分強が放水路に流入する.

鈶直方向に等間隔で歩道橋橋脚に設置した 5 個の 水温塩分計と水圧式水位計および大気圧計により, 水温, 塩分, 水位を 20 分間隔で連続測定した. 水 温塩分計の河床からの設置高さは $0.2,1.2,2.2,3.2$, $4.2 \mathrm{~m}$ である. 河床側 3 点の塩分測定には生物付着な どの污れの影響を防ぐためにワイパー式水温塩分計 （アレック電子製 CTW）を用いた。測定期間は2006 年 5 月 25 日 9 時〜 9 月 18 日 18 時と 2006 年 10 月 25 日 12 時〜 2007 年 2 月 28 日 10 時である.

さらに，2006 年 11 月 28 日 11 時から 2007 年 1 月 22 日 10 時の間は図-1(b)に示すように，水温塩分計を 取り付けた橋脚から右岸側に $8 \mathrm{~m}$ 離れた最深部の河
床上に，超音波の周波数が $3 \mathrm{MHz}$ の $\mathrm{ADP}$ を設置し， 流速と散乱強度の鉛直分布を連続測定した。平均時 間は 1 分，セル厚は $15 \mathrm{~cm}$ ，測定間隔は 10 分とした。 図-1(b) に示す $2 つ の$ 水面の位置は観測期間内に測定 された最低水位と最高水位の位置を示している.

\section{3. 塩分の変動特性}

\section{(1) 塩分の短期変動}

図-2 と図-3 に出水期と平水期の観測結果を示す. 上から順に，矢口第 1 観測所（分派点の約 $5 \mathrm{~km}$ 上流） での河川流量，塩分の鉛直分布，河床から $4.2 \mathrm{~m}$ と $0.2 \mathrm{~m}$ における塩分の経時変化である。ここで， $z$ は河床からの高さ， $S_{s}$ と $S_{b}$ はそれぞれ河床から $4.2 \mathrm{~m}$ と $0.2 \mathrm{~m}$ の高さにおける塩分である.また, 図$2,3(\mathrm{~b})$ の黒線は水面の位置を表している. なお, 各 国際委員会（SCOR, IAPSO, ICES, IOC）の勧告に より塩分には単位を付けないこととなっている. 
(a)

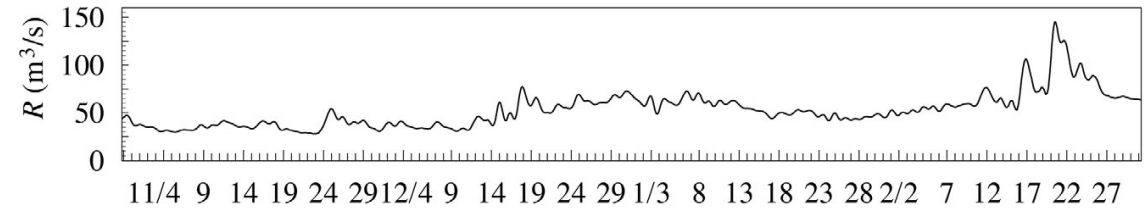

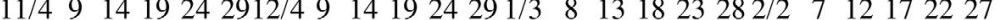

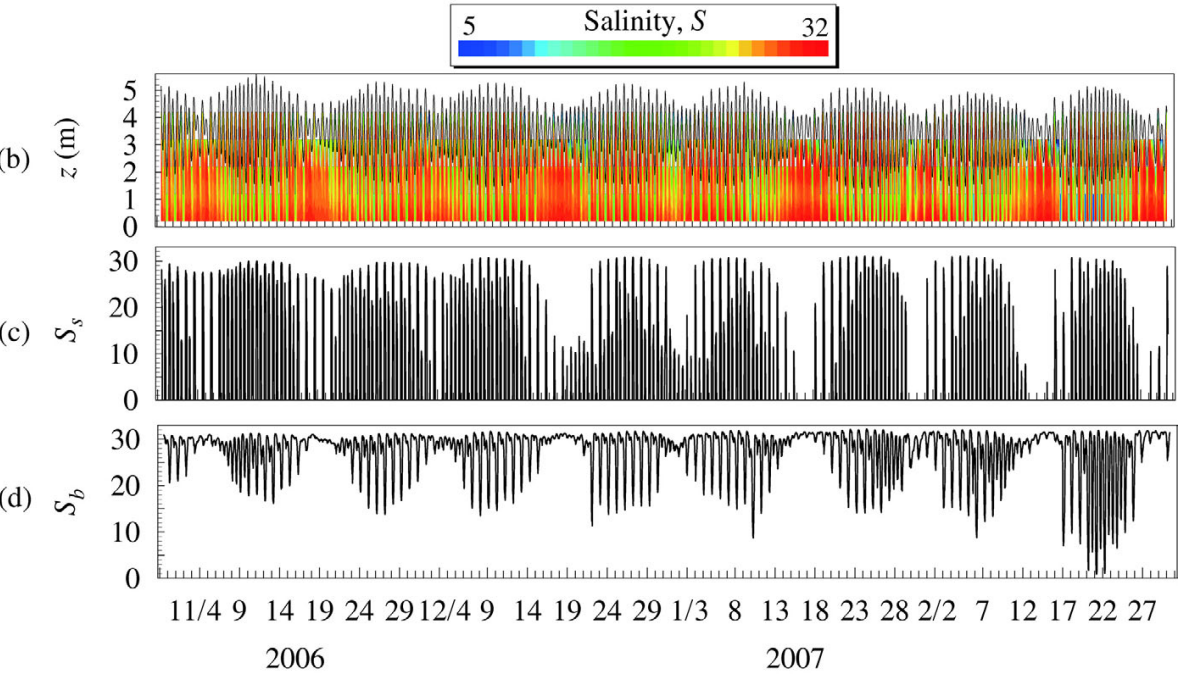

図-3 平水期における河川流量 $(\mathrm{a})$ ，塩分の時空間分布 $(\mathrm{b})$ ，上層塩分 $(\mathrm{c})$ と底層塩分 $(\mathrm{d})$ の経時変化
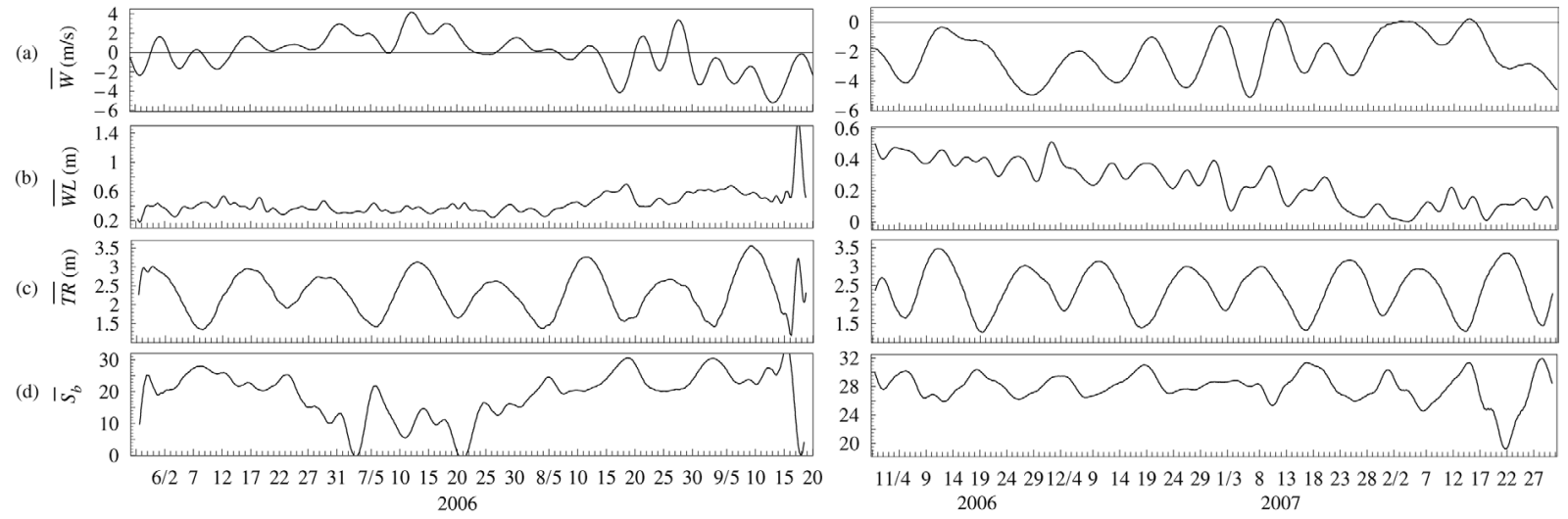

図-4 水路に沿った平均風速 (a), 平均水位 (b), 平均潮差 (c) と底層平均塩分 (d) の経時変化

最大潮差が約 $4 \mathrm{~m}$ と大きいため, 図-2,3(b)の塩分 鉛直分布には水柱全体の塩分を測定できていない時 間帯が存在していることに注意する必要がある。ま た，図-2,3(c) に示す $S_{s}$ が 0 となっているのは，出 水時を除けば，センサーが干出していることが原因 である。図-2 の観測期間内に祇園水門が全開となる $400 \mathrm{~m}^{3} / \mathrm{s}$ を超える出水が 5 回起きている. 図-2(d)の 底層塩分をみると, 祇園水門が全開となっている期 間では潮汐位相にかかわらず塩分は 0 となっており, 塩水は観測地点まで到達していない。水門操作に対 する底層塩分の応答はかなり速く, 水門が平常時の 状態に戻ると, 上げ潮期の 6 時間で底層塩分は 0 か ら 20 程度の值まで回復している。上層塩分の回復は 底層に比べると遅く, 出水前の值に復帰するのに 20 日程度を要している。

既に報告したように ${ }^{1)}$ ，大潮期の塩分は潮汐位相 によって大きく変動しており, 底層の塩分は低低潮
時にスパイク的に減少している.また, 後述するよ うに日平均塩分は大潮期より小潮期の方が高い.

\section{(2) 底層塩分と成層強度の長期変動と変動要因}

塩分の長期変動を引き起こす主な要因として, 河 川流量, 風, 潮差, 平均水深が考えられる. ウェーブ レットフィルターを用いて日周潮以下の変動を除い た長周期変動（日平均值）の経時変化を図-4に示す. 上から順に, 平均風速 $\bar{W}$, 平均水位 $\overline{W L}$, 平均潮 差 $\overline{T R}$, 底層の平均塩分 $\bar{S}_{b}$ である. 風速 $W$ は広島 気象台の風速・風向データを放水路に沿った風速に変 換したもので，風向は放水路上流方向を正としてい る. 図-4(a)の平均風をみると, 夏季は上流方向, 冬 季は下流方向の風が卓越している。平均水位の経時 変化には, 9 月が最も高く 2 月に最低となる年周期の 変動に加え, 8 月と 9 月中旬には台風の接近にともな う気圧低下に対応した変動が存在している。 
表-1 底層塩分と成層強度の変動に対する 重回帰分析の結果 （出水期 : 2006/5/25-9/18)

\begin{tabular}{lrrrcc}
\hline & $\beta_{1}$ & $\beta_{2}$ & $\beta_{3}$ & $\beta_{4}$ & $r^{2}$ \\
\hline$\overline{S_{b}}$ & -4.41 & -2.71 & -1.25 & 2.84 & 0.629 \\
\hline $\bar{\phi}$ & -4.06 & -0.907 & -5.63 & 0.849 & 0.41 \\
\hline
\end{tabular}

表-2 底層塩分と成層強度の変動に対する 重回帰分析の結果

(平水期 : 2006/10/25-2007/2/28)

\begin{tabular}{cccccc}
\hline & $\beta_{1}$ & $\beta_{2}$ & $\beta_{3}$ & $\beta_{4}$ & $r^{2}$ \\
\hline$\overline{S_{b}}$ & -0.648 & -0.197 & -1.59 & 0.076 & 0.747 \\
\hline $\bar{\phi}$ & 3.71 & 0.982 & -2.68 & 2.14 & 0.37 \\
\hline
\end{tabular}
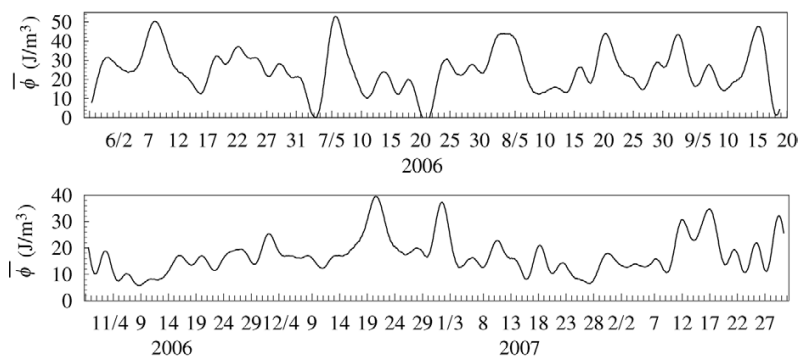

図-5 成層強度の経時変化

図-4(d) の平均底層塩分の経時変化をみると, 図2(a)に示されている出水にともなう大きな減少のほ かに, 潮差の増減に対応した変動が明瞭にみられる. すなわち，小潮期は大潮期に比べ高塩分となってい ることがわかる。これは主に, 潮流の強さに応じて 鉛直渦動粘性係数が増減するためで, 大潮期は鉛直 渦動粘性係数が大きくなるため塩水遡上が抑制され ている。

上流方向の風によって誘起される吹送流は底層の 塩水遡上を妨げ，下流方向風は逆に遡上を助長する. 風の影響度は潮差にも関係し，小潮期に顕著である

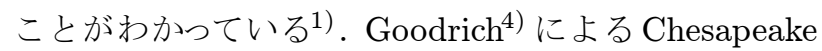
湾における観測では，風による流れが密度流より一 般的に大きく, 特に風が発生している間は潮汐流と 同じオーダーになり得ることが示されている.

底層塩分に対する潮差や風などの影響度合いを調 ベるために，(1) 式の線形回帰式を用いて重回帰分析 を行った結果を表-1および表-2 示す.

$$
\widehat{S}_{b}=\beta_{0}+\beta_{1} \widetilde{R}_{G}+\beta_{2} \widetilde{W}+\beta_{3} \widetilde{T R}+\beta_{4} \widetilde{W L}
$$

ここで， $\widehat{S}_{b}$ は日平均底層塩分 $\bar{S}_{b}$ の回帰推定值， $R_{G}$ は放水路流入量である。〜標準偏差による基準 化を意味している。したがって, 偏回帰係数 $\beta_{i}$ の絶 対值は各要因（説明変量）の影響度合いを示すこと になる。前述したように，放水路に流入する河川流 量は祇園水門の操作により大きく変化する. 感潮域 であるので, 放水路流入量 $R_{G}$ の正確な值は不明で

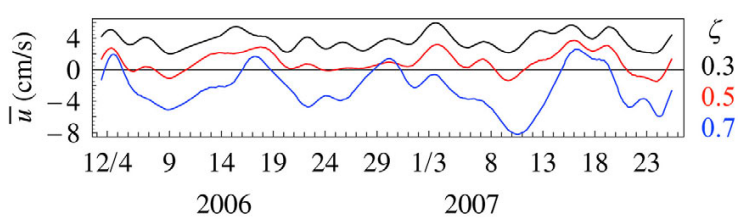

図-6 残差流速の経時変化

あるが，太田川河川事務所の計画值に従って，矢口 第一流量観測所の測定值 $R$ から次式で推定した。

$$
R_{G}=\left\{\begin{array}{l}
0.1 R \text { for } R<400 \mathrm{~m}^{3} / \mathrm{s} \\
0.53 R \text { for } R \geq 400 \mathrm{~m}^{3} / \mathrm{s}
\end{array}\right.
$$

表-1, 表-2 中の $r^{2}$ は寄与率, $\phi$ は後述する成層強 度パラメーターである. 表-1の出水期の結果を見る と, 底層塩分に最も大きく影響しているのは流入量 で, 平均潮差の影響度は最も小さい。平均風と平均 水位は同程度の影響度をもっている。河川流量, 上 流方向風, 潮差の増加は塩水遡上を妨げ, 平均水位 の増加は塩水遡上を強めている。これら 4 つの説明 変量によって底層平均塩分変動の約 $63 \%$ が説明され る. 風と潮差の影響は数值モデルで示された結果 ${ }^{3)}$ と一致している.

表-2 に示すように，平水期における潮差の影響の 仕方は出水期と同様であるが, 潮差の影響度が 4 つ の説明変量の中で最も大きくなっている点が異なっ ている. 平均水位は 2 月に向かって約 $0.5 \mathrm{~m}$ 減少して いるが，この影響はほとんどない。回帰式の寄与率 は出水期より大きく, 底層平均塩分変動の約 $75 \%$ を 説明できている。

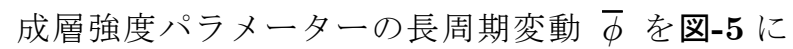
示す. $\phi$ は成層状態にある水柱を一様な状態にする のに要する単位体積あたりのエネルギーである ${ }^{1,5)}$. 历の経時変化には潮流による鉛直混合の影響を受け て潮差に対応した変動がみられる。ささらに, 祇園水 門が全開となる出水時は，水柱全体の塩水がフラッ シュされているので密度成層は消滅している.

表-1, 表-2 に示す (1) 式と同様な回帰式を用いた $\bar{\phi}$ に対する回帰分析の結果を見ると, 出水期と平水期 では河川流量と風が密度成層強度に与える影響が逆 になっていることがわかる. 寸なわち, 適度な河川流 量（水門が平常状態）は密度成層を強めるが，水門 が全開となって流入流量が大きくなりすぎると, 塩 水が遡上できなくなるため, 密度成層は消滅する.

風速は表層における淡水の移流と鉛直混合をコン トロールするが, 河川流量が少なく北風が卓越する 冬季には, 風は鉛直混合を通して密度成層の強さに 影響しているため， $\beta_{2}$ が正となっていると考えられ る（北風による鉛直混合により成層強度が減少）。

\section{4. 平水期における残差流の変動と塩水, 懸濁 粒子の輸送特性}

\section{(1) 残差流の変動}


表-3 残差流と移流フラックスの変動に対す る重回帰分析の結果

(平水期：2006/11/28-2007/1/22)

\begin{tabular}{lccccc}
\hline & $\beta_{1}$ & $\beta_{2}$ & $\beta_{3}$ & $\beta_{4}$ & $r^{2}$ \\
\hline $\bar{u}_{0.3}$ & -0.019 & -0.125 & -0.74 & -0.261 & 0.512 \\
\hline $\bar{u}_{0.5}$ & 0.062 & -0.471 & -1.16 & -0.118 & 0.712 \\
\hline $\bar{u}_{0.7}$ & 0.024 & -1.04 & -2.1 & 0.275 & 0.624 \\
\hline$\overline{s_{f}}$ & -0.05 & -0.02 & -0.686 & -0.16 & 0.64 \\
\hline$\overline{s_{v}}$ & -0.16 & -0.671 & 2.85 & 0.311 & 0.848 \\
\hline$\overline{s_{v} u_{b}}$ & -14.8 & -10.9 & 52.7 & -19.8 & 0.786 \\
\hline
\end{tabular}

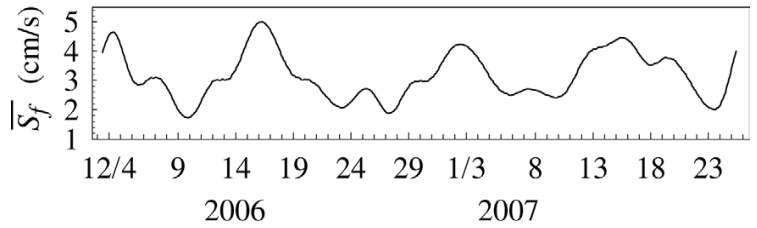

図-7 海水遡上速度の経時変化

図-6 に相対高さ $\zeta(=z / h)=0.3,0.5,0.7$ における 残差流の経時変化を, 回帰分析の結果を表-3に示す. 本論文では, 日周潮以下の周期変動を除いた主流方 向流速の日平均值を残差流としている.

下層 $\zeta=0.3$ では観測期間を通して残差流は上流 方向である. 鉛直方向の流速差は潮流による鉛直混 合の強さに応じて大潮期に小さく，小潮期に大きく なっている.

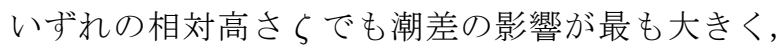
数值計算結果 ${ }^{3)}$ と同様, 潮差が小さくなるほど上流 方向の残差流が大きくなっている。こうした残差流 (密度流）の変動が, 前述した塩分の長期変動を引き 起こしている主原因であると考えられる.

\section{(2) 海水遡上速度の変動}

塩水中の海水の割合は, 海域の平均塩分を $S_{0}$ と すれば， $S / S_{0}$ で求められる ${ }^{6)}$. 広島湾の平均的な 塩分は 32.5 であるから, 底層における広島湾起源の 海水の移流（遡上）速度は次式で評価できる.

$$
S_{f}=u_{b} \frac{S_{b}}{32.5}
$$

ここで， $u_{b}$ は $z=0.2 \mathrm{~m}$ での底層流速である.

図-7に(3) 式で求めた底層における海水の平均遡 上速度の経時変化を示す. 底層における塩分と残差 流はともに潮差と逆相関にあるので, 平均遡上速度 の経時変化には大潮-小潮周期が明瞭にみられる。観 測期間の平均遡上速度は $1.5 \sim 5 \mathrm{~cm} / \mathrm{s}$ の範囲で変動し ている。表-3 の回帰分析結果をみると，平水期には 説明変量の中で潮差が平均遡上速度に与える影響が 圧倒的に大きいことがわかる.

\section{(3) 懸濁粒子の輸送特性}

(a)

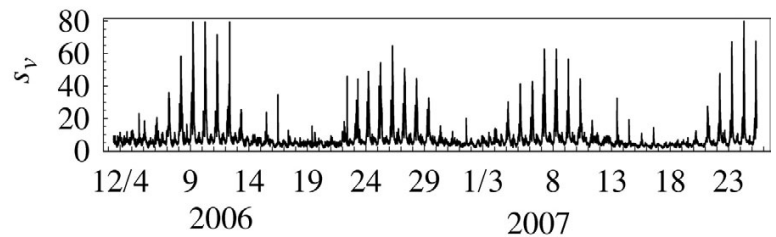

(b)

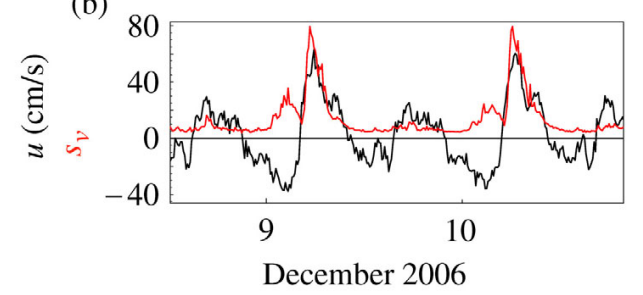

図-8 体積後方散乱係数 (懸濁粒子濃度) の経時変化

(a) 15

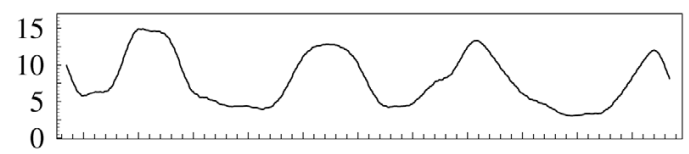

(b)

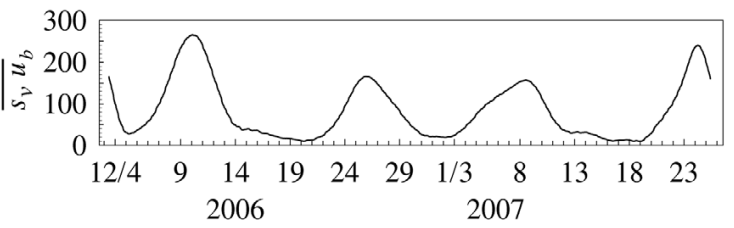

図-9 底層における体積後方散乱係数（懸濁 粒子濃度）とフラックスの長期変動

懸濁粒子の粒径が大きく変動しなければ，超音波 の体積後方散乱係数は䀣濁粒子の体積濃度に比例す $ろ^{7)}$. ADP の散乱強度からノイズレベルを除き, 音 波の伝播損失を補正すれば体積後方散乱係数に比例 する值（ $s_{v}$ で表す）が得られるので 7$)$, 採水濾過し て求めた濃度を使ってキャリブレーションを行えば, 散乱強度から㲘濁粒子濃度が求められる。本研究で は残念ながら採水を行っていないので, 懸濁粒子濃 度に変換することは出来ないが，䀣濁粒子濃度の定 性的な変動は知ることが出来る。

図-8(a) に底層 $z=0.2 \mathrm{~m}$ での $s_{v}$ の経時変化を示 寸. 本研究の観測地点より $2 \mathrm{~km}$ 下流で得られている 結果 ${ }^{2)}$ と同様に $s_{v}$ は小潮期は小さく, 大潮期に間 欠的に上昇している. 日潮不等のため, 大きなピー クは一日周期で発生している. 大潮期の経時変化を 拡大した図-8(b) をみると， $s_{v}$ の大きなピークは上 げ潮初期の最大流速と同時に発生していることから， 潮流による河床堆積物の巻き上げによるものである ことがわかる.

図-9(a)に $s_{v}$ の日平均值 $\bar{s}_{v}$ の経時変化を示寸. 平 均潮差に対応した変動が明瞭にみられる.表-3 の回 帰分析結果をみると， $\bar{s}_{v}$ の変動に対して潮差の影響 度が突出している. (1) 式と同様な線形回帰式で $\bar{s}_{v}$ 変動の大部分 $(85 \%)$ が説明できている.ただし, 図10(a) に示すように， $\bar{s}_{v}$ とその線形回帰推定值の関 係は線形ではない. 


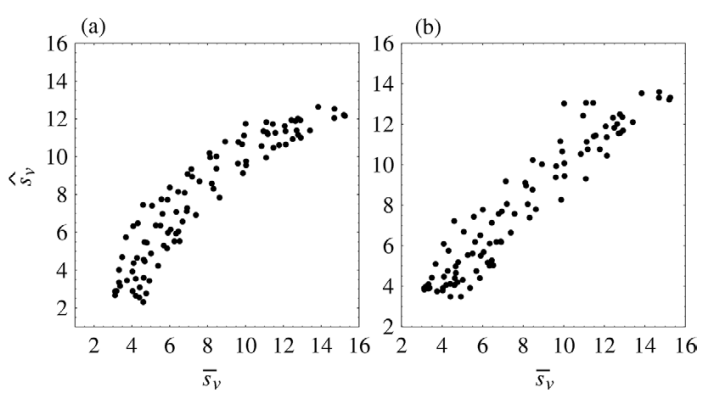

図-10 底層における体積後方散乱係数（懸濁粒 子濃度）の回帰推定值と観測值の関係

$\bar{s}_{v}$ の変動が潮流による堆積物の巻き上げによって 生じているとすれば, 潮差と $\bar{s}_{v}$ の関係は線形では ない。近似的に流速は潮差に比例するので，底面せ ん断応力 $\tau_{b}$ は潮差の 2 乗に比例することになる.ま た，粘着性堆積物の浸食速度 $E$ は一般に

$$
E \propto\left(\tau_{b}-\tau_{c}\right)^{n}
$$

のように表される ${ }^{8)}$ 。ここで， $\tau_{c}$ は限界底面せん断 応力, $n$ は堆積環境に依存する定数である. $\bar{s}_{v}$ の 回帰式として

$$
\widehat{s}_{v}=\beta_{0}+\beta_{1} \widetilde{R}_{G}+\beta_{2} \widetilde{W}+\beta_{3} \widetilde{T R}^{m}+\beta_{4} \widetilde{W L}
$$

を使用して非線形最小 2 乗法で求めた $m$ は 3.9 で あったので， $n$ は 2 程度の大きさであると推測され る. 表-3 中に斜体で示しているように，(5)式の回帰 式を使った場合の寄与率は線形回帰式の場合より大 きく 0.898 であった。(5) 式で求めた回帰推定值と観 測值の関係を図-10(b) に示す。両者の関係は線形に なっている。

図-9(b) は底層における懸濁粒子の移流フラックス $\bar{s}_{v} u_{b}$ の経時変化を示したものである.ただし, キャリ ブレーションを行っていないので, 実際のフラックス とは定数倍異なっている。このため単位は付けてい ない. 出水がなかった観測期間の結果である図-9(b) は, 潮汐変動を除くと底層懸濁粒子が上流方向に運 ばれていることを示している。また，輸送量は潮差 とともに大きくなっていることがわかる。こうした 結果は, 本観測点から $2 \mathrm{~km}$ 下流地点で著者らがこれ まで行ってきた結果 $\left.{ }^{2}\right)$ と同様であり，上げ潮初期に流 速と懸濁粒子濃度が最大となるためである（図-8）。

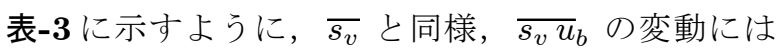
潮差が最も影響しているが, 平均水深の影響の仕方 は逆である。これは，平均水深が小さくなると干潮 直前の下げ潮流速が底層でも大きくなり，下流方向 フラックスが増加するためである。

潮差と $\bar{s}_{v} u_{b}$ の関係は非線形である. 非線形最小 2 乗法を適用すると $\widetilde{T R}^{7.36}$ となり（他の項は 1 次）, 輸送量は潮差とともに急激に大きくなることがわか る. 寄与率は 0.936 である，潮差の項の大きなべき
指数は, 流速が潮差とともに大きくなることに加え, Taidal straining ${ }^{1)}$ に起因していると考えられる.

\section{5. 結論}

潮汐による水深変化が大きく, また, 上流端の水門 操作によって著しい非定常性を示す太田川放水路の 中流部において，4 ケ月にわたる塩分分布の連続観 測を出水期と平水期の 2 回実施し, 塩水遡上の動態

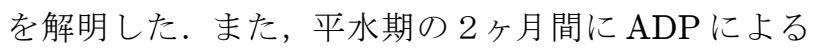
流速分布と懸濁粒子濃度の連続測定を行い, 残差流 と海水の遡上速度, 懸濁粒子フラックスの変動特性 を明らかにした。すなわち, 以下のことが判明した。

放水路上流端にある祇園水門が全開となる出水時, 塩水は完全にフラッシュされるが, 水門が平常の状態 に戻ると上げ潮流によって底層塩分は速やかに回復 する.

大潮期は鉛直渦動粘性係数が大きくなるため塩水 遡上が抑制される.また, 河川流量と上流方向の風 も塩水の遡上を妨げる. 反対に, 平均水深の増加は 塩水の遡上を助長する. 潮差が小さくなるほど上流 方向の残差流が大きくなり，底層塩分が上昇する.

懸濁粒子の平均濃度は潮差とともに増加する。平 水期の懸濁粒子の平均フラックスは上流方向で, 潮 差とともに急激に増加する. 上流方向風は懸濁粒子 の遡上を妨げる. 平均水深の減少は平均濃度を増加 させるが, 上流方向の平均フラックスは減少させる.

謝辞 : 本研究の一部は科学研究費基盤 $\mathrm{C}$ (課題番号 : 18560499, 研究代表者: 川西 澄) および (財) 河川環 境管理財団 河川整備基金の補助を受けて実施したも のである。ここに記して，深甚なる謝意を表します。

\section{参考文献}

1) 川西澄・筒井孝典：浅水感潮域における密度成層の 変動特性, 水工学論文集, 第 48 巻, pp. 781-786, 2004.

2) 川西澄・筒井孝典・中村智史・西牧均: 太田川放水路にお ける河川流量と潮差変動に伴う浮遊砂泥の輸送特性, 水工学論文集, 第 49 巻, pp. 650-654, 2005.

3) 川西 澄・荒木大志・福岡捷二・水野雅光 : 風が太田川 河口域の塩水遡上と土砂輸送に与える影響, 海岸工学 論文集, 第 54 巻, pp. 781-786, 2007.

4) Goodrich, D. M.: On stratification and wind-induced mixing in the Chesapeake Bay, PhD thesis, Marine Sciences Research Center, State Univ of New York, Stony Brook, N.Y.

5) Simpson, J. H. and Hunter, J. R.: Fronts in the Irish Sea, Nature, Vol. 250, pp. 404-406, 1974.

6) 柳 哲夫 : 沿岸海洋学, 153 pp., 2001.

7) 川西澄・水野博史: 浅水感潮域における水中音響散乱 体の変動特性, 水工学論文集, 第 45 巻, pp. 1045-1050, 2001.

8) Black, K. S., Tolhurst, T. J., Paterson, D. M. and Hagerthey, S. E.: Working with Natural Cohesive Sediments, J. Hydr. Engrg., Vol. 128 (1), pp. 2-8, 2002. 